\title{
An empirical study of World Bank agricultural development programme in Nigeria
}

\author{
${ }^{1}$ Emma Chukwuemeka, Ph.D and ${ }^{2}$ Dr. (Mrs.) Hope N. Nzewi
}

${ }^{1}$ Senior Lecturer, Department of Public Administration, Nnamdi Azikiwe University, P.M.B. 5025, Awka, Nigeria, Tel: 08060967169; 08052671039, E-mail: hrvkonsult@yahoo.com

${ }^{2}$ Department of Business Administration, Nnamdi Azikiwe University, Awka Nigeria

\begin{abstract}
This study evaluated the extent World Bank sponsored Agricultural Development Project has gone in Nigeria with a view to identifying the areas of problems. In pursuant of this objective, survey research method was adopted. Data collected through questionnaire were presented in tables and analyzed. The findings revealed among others, that policy approach that excluded the beneficiaries from participating in the project design, planning and implementation is not desirable. Recruitment of extension staff were not based on expertise and professionalism, but on political considerations. The three financiers - World Bank, Federal and State governments of Nigeria do not make their contributions as and when due. Frequent change in leadership has also affected the operation of World Bank sponsored ADP. Based on the findings, the major recommendations are: That ADP should open a dialogue with the government explaining the need to maintain a recruitment policy based on merit as well as less government intervention in the recruitment policy of the Programme. The Federal Government of Nigeria should as a matter of necessity, redesign the ADP to give each state ADP a corporate status that will enable it have access to the financial market in order to procure development loans on its own capacity. There is need to involve the project beneficiaries in the design, planning and execution of the project. This will equally avoid top down approach in policy coordination. It will also stimulate the interest of the recipients or host communities.
\end{abstract}

Keywords: Agricultural development, World Bank, Political intervention, Policy

\section{INTRODUCTION}

With the discovery of crude oil in Nigeria and the subsequent oil boom in the 1970s, far less attention was given to agricultural sector which hitherto had been the foreign main income earner for Nigeria. With the resultant decline in agricultural production, Nigeria became a net importer of both food items and agro-allied raw materials. The cumulative effect of this situation is that the agricultural sector failed to perform its traditional functions effectively. To meet up with the crisis, both the federal and state governments formulated several policies and embarked on a variety of agricultural programmes aimed at improving the capacity of the agricultural sector. This new interest is demonstrated by the establishment of the Operation Feed the Nation, Green Revolution, the Directorate of Food, Road and Rural Infrastructure, the River Basin and Rural Development Authorities and the current World Bank assisted Agricultural Development Progranne (ADP) (Okereke, 2000).
World Bank has championed agricultural development programme in Nigeria in form of foreign aid. The programme which started with emphasis on increased food production, was conceived in 1972 and effectively commenced in 1975 in Northern Nigeria in the enclave (experiment) areas of Funtua, Guzau and Gombe (Abah, 2001).

The success of these experiments led to the establishment of state- wide projects in Kaduna, Sokoto and Bauchi as off-shoot, the multi-state ADPs designed by the Federal Government Agricultural Coordinating Unit (FACU) were to cover some states in the middle Belt and South (Anambra, Bendel, Cross River, Imo, Ogun, Benue and Plateau states of Nigeria) (Chuwkwuemeka, 2004). In furtherance to the Bank's objectives, International Fund for Agricultural Development (IFAD) was also established to help in improving cassava farming among rural farmers. What we have today as the multi-state ADP is the product of the joint effort of the World Bank and IFAD which culminated in the 
granting of a N162 million loan in 1984 (ADP, Monitor, 1994).

The approved ADP programme was funded by:

(a) The World Bank - providing $66 \%$ of total project cost contributed in civil works,

Plants, vehicles, equipment, spare parts, training and consultancy.

(b) The Federal Government: providing 19\% in input procurement, chemicals and

Pesticides and

(c) The State Government - providing 15\% in salaries and general services.

The ADP does not engage in direct food production, rather, services and infrastructures are provide, while the farmers do the production.

\section{The objectives of the programme include:}

(a) To improve the farm income of small holder farmers through integrated rural development programmes.

(b) To support the Federal Government objective, in food production through the improved production of cassava, yam, maize and rice.

(c) To raise the living standards of the rural population.

(d) To revitalize and reorganize agricultural extension services through the training and visiting system

(e) To commercialize and improve existing farm input distribution system

(f) To provide all-season access roads to rural farming communities by establishing and maintaining rural feeder roads.

(g) To establish On-farm Adaptive Research (OFAR) as a means of developing and disseminating information.

(h) To sponsor and encourage the processing, storage and marketing of primary farm inputs.

These objectives were to be achieved through the following sub-programmes:

(i) Crop and farm development

(ii) Agricultural research/Extension (iii) Commercial services

(iv) Establishment and maintenance of a project monitoring/evaluation, planning and manpower development and training components (Eze, Chukwuemeka, and Abah 1998)

Statement of Problem: For more than two decades now, the agricultural sector of the Nigerian economy has continued to perform below expectation despite the huge sums of money being allocated to the sector in each year's budget (Onyeahialam, 2002).

In 2002, about N9.874 billion was mapped out for the sector (Obasanjo, 2002). Also during the same year, 72 million dollars donated by Food and Agricultural Organisation (FAO) were distributed to the 36 states of the federation in addition to the years' allocation (Iheagu, 2002). According to Iheagu (2002), the money cannot be said to have been justifiably used, rather, what one sees is the prevalent poor attitude of the government to the execution of agricultural programmes.

The warming signals are being confirmed on daily basis by high price of food items in the market and the crude system of farming being practiced in the country. This situation raises questions as to the effectiveness of the World Bank assisted Agricultural Development Programme which was established in the belief that such project can radically transform agriculture and increase the Country's food and fibre needs of the rapidly increasing population. In spite of the presence of ADP, food shortages have been getting worse from year to year. For instance in 2006, the Country's Gross Domestic Product (GDP) at 2002 constant factor cost was N83.5 billion agriculture contributed a total of N33 billion or $40.5 \%$ (NBS, 2007). However, at current factor cost, this sector's contribution to GDP declined from $22 \%$ in 2003 to $28 \%$ in 2008 with unsteady improvement to $31.3 \%$ in 2009 and $6.7 \%$ in 2002 , due to unsteady productivity of the agricultural sector (CBN, 2009).

Something therefore must be wrong with the World Bank assisted Agricultural Development Programme Policy, its contents and implementation strategies which, over the years of its operation has caused the agricultural sector to remain almost stagnant. In short, the World Bank Agricultural Policy has been faced with a dilemma. The problem is much more confounding than it meets the eye when one realizes that the peasant farmers in most parts of Nigeria, especially Enugu State still engage in 'primitive' and 'traditional' method of agricultural production. 
Eighteen years is long enough a time to justify a purposeful appraisal of the Enugu State ADP. This has called for persistent search for the problems that militate against the implementation of the World Bank assisted Agricultural Development Programme in Nigeria.

Objectives of the Study: The broad objective of the study is to examine the performance of World Bank assisted Agricultural Development Programme in Nigeria and especially in Enugu State.

The specific objectives of the study are therefore to:

(i) examine the extent to which ADP has contributed to agricultural development inNigeria

(ii) investigate the major factors that has hampered the effective performance of ADP in agricultural development

(iii) investigate how effective ADP is funded

(iv) examine the effectiveness of ADP policy design and the impact it has made on the programme implementation

(v) proffer solutions to the identified problems.

\section{Hypotheses}

Political interference in leadership and recruitment in ADP by success governments has impeded the actualization of the programme objectives

Ineffective funding is the cause of the inability of World Bank Agricultural Development Programme to impact positively on agricultural production

Non involvement of the programme beneficiaries in policy planning impairs the smooth implementation of the programme.

\section{METHODOLOGY}

The descriptive research method was used in carrying out the investigation. This method was chosen because; it is the method that best interprets World Bank and agricultural development, without loss of facts. Specifically, two descriptive research methods were used, namely, sample survey and case study of Enugu State of Nigeria.

Questionnaire, face to face interview and personal observation were used for data collection.

(1) Efforts of the World Bank to develop agriculture in Nigeria: A buoyant agricultural sector is vital to the Nigerian economy. The sector contributes more than one third of Gross National Development (GNP) and is an important source of exportable and of raw materials for domestic industries (World Bank Publication, 1993). Agricultural productivity and rural incomes therefore need to grow rapidly if there is to be significant progress in alleviating poverty and food insecurity and in generating inevitable savings. Yet agricultural growth in Nigeria is still low.

Tamuno (2006) argues that Nigeria's diverse agroecological conditions permit a range of farming systems but current productivity of both land and labour is low. Agriculture is predominantly the business of small holders. Women account for much of the agricultural labour force; and the problem of low labour productivity is partly rooted in the gender specific allocation of responsibilities in rural production and household maintenance system. Farming has traditionally been based on shifting cultivation, relying on prolonged fallowing to restore soil fertility. With rising population pressure, fallow periods have been shortening, but farmers have been slow to adapt their farming practices to take into account these changed circumstances. Major impediment to the adoption of the necessary changes contends Tamuno (2006) concern on-farm labour scarcity at critical times, notably the intensifying time constraint on rural women, lack of ergonomically appropriate and financially attractive technology poor access to input and to output market and complex land rights issues. However, most constraints particularly those relating to policy infrastructure and technology were addressed by the World Bank Agricultural Development Programme.

Scholars have varying opinions on the poor state of our agricultural sector. Notable among such scholars is Afigbo (2000). He argues that agricultural performance was poor during the oil boom of the 1970 s as the naira became over valued, public expenditure concentrated on other sectors, and made young men left the rural areas for employment in the rapidly expanding non-agricultural sectors. Obiajulu (1997) argues that the problem was compounded by the effects of poor rains throughout the 1980s and early 1990s. The situation led to problems in the production of cereal and root crops. While we agree with the two situations, it is important to note that even when the oil boom ended in the early 1980s, agricultural performance remained severely constrained by a combination of poor weather and adverse policies including an overvalued currency, 
price controls, trade restrictions, and the inefficient operations of commodity marketing boards.

Agricultural growth however began to revive in the mid 1980s, leading to the rising GDP at an estimated average rate of about $6 \%$ between 1984 and 1986, and about $3.8 \%$ thereafter (World bank publication 1993). Three factors combined to promote this growth, 1984 was the first year with good rainfall in Northern Nigeria after the long drought of the 1970s and early 1980s, the northern states established state wide Agricultural Development Projects (ADPs) with a smallholder orientation and a focus on extension, input distribution and rural infrastructure, and by the mid-1980s these efforts were beginning to pay off, with the progress recorded by the pilot ADP in the North, it was made a Nation wide affair. The first multi-state agricultural development projects (MS ADP-1) loan No. 2733 UNI for US \$162.0 million appraised in May/June 1984 was a follow up to a number of enclave and state wide projects initiated in the 1970s, with the broad objective of improving farm income of small holder farmers through a set of integrated rural development programmes (ADP publication, 1995). The main objective of the World Bank MS ADP, include:

(i) Increased food production and farm income mainly cassava, yam, maize and rice

(ii) Develop a flexible phased approach to development with initial emphasis in implementing well proven components geared to the agricultural potential and within the financing and managerial capacity of the benefiting states, while embarking on an intensified programme of adaptive on farm agricultural research.

(iii) Assisting benefiting states in rationalizing current activities through a move to reorganise and commercialise input distribution and develop a smaller but more effective extension services.

(iv) Prepare for the transfer of a greater share of the responsibility for project appraisal and suspension to Nigerian institutions.

(v) To raise farmers income through increase food production

(vi) To upgrade rural roads and water supplies to rural farms

(vii) To develop adequate extension, credit and marketing services for the farmers (viii) To provide farm input to farmers at reasonable prices

(ix) To encourage the maintenance of agricultural lands by good conservation methods.

In spite of all these efforts the World Bank assisted Agricultural Development Programme has not transformed the lives of the people. Several scholars including Olatunbosun (2005) have tried to explain the problem of persistent food crisis and rural backwardness in Nigeria. In his work, he has identified a number of factors as the main explanatory variables. Some of these are ignorance, uncoordinated agricultural development efforts/programmes, poor agricultural policy planning, infrastructural problems, technical know-how and poor equipment utilization, high dependence rate and lack of political will power. To some other scholars like Onimode (2008) and Nzimiro and Eteng (1976), the enduring and worsening conditions of agriculture stem from the existence of capitalism with its exploitative tendencies. They cited the case of ADP whereby the co-ordinators collude with the government to misappropriate the resources of the programme. There is a third category that thinks that government's faulty conceptualization and implementation of agricultural development policies and programmes constituted the root of Nigeria's agricultural development backwardness (Ojian, 1987, and Famoriye, 1998). They went further to stress that, even though the idea of the ADP on its totality is good, but it has a lot of weaknesses both in policy planning and implementation. According to them, the World Bank ought to liaise with the programme beneficiaries in formulating the ADP policy. This would have given the Bank the opportunity to identify the political, socio-cultural and technical variables that now bedevil the programme.

Ojowu (1987) also criticizes the Government for their ineffective funding of the various post-colonial agricultural development programmes in Nigeria. Generally, the World Bank Agricultural Development Programme has not performed for instance in 1993, Enugu State Agricultural Development Programme ranked second in performance among other south eastern ADPs in the Nigeria, after 1993, the Programme's performance chart dropped to its lowest ebb (ENADEP Annual Report, 1996). The report revealed that the reason for this was because of poor counterpart funding of the programme by the State, Federal governments and the World Bank. 
ENADEP Annual Report (1996) also revealed that among other inhibiting factors to the programme implementation range from frequent changes in leadership of the programme.For instance between 1992 and 2008 Enugu State ADP has changed eight programme managers. The same thing obtains across other ADPs in Nigeria. The sum total of these contends Umebali (1999), is persistent food crisis and rural backwardness of Nigeria. World Bank publication (1993) holds a similar view with Umebali. It argues that constitutionally, responsibility for agriculture is shared between the Federal and State governments (like the World BankADP).The Federal Government sets basic policies and national priorities and the states, through their ministries of agriculture and natural resources (MANRs), are meant to have primary responsibility for programme implementation. In practice, FGN exercises considerable control over the states activities, and the allocation of development funds is dominated by decisions made at the federal level.
The failure of ADP in Nigeria argues Uzoigwe (2007) is largely due to the ineffectiveness of the extension agents, some of whom are non-specialists. Thus, some of them studied courses not related to agriculture, but due to political consideration, they were employed as extension agents.

Findings and Discussion: Here the findings of the investigation are discussed. Information obtained through interviews supplements the information obtained through the secondary sources of data.

(1) sGrowth in crop production (Pre-ADP and post-ADP periods): The performance of Agricultural Development Programme vis-à-vis crop production is not very satisfactory. For instance, table 1 and 2 below, reveal that there is remarkable disparity between the production of rice, maize and cassava for the period (2000-2008) compared to pre-ADP period (1971-1976). This therefore suggests that no significant impact has been recorded in the operation of ADP in the area of crop production in Nigeria.

Table 1 - Output of major food crops ('000 tones) 1971-1976 (Pre-ADP period)

\begin{tabular}{|l|l|l|l|l|l|l|}
\hline Year & Millet & Rice & Maize & Beans & Cassava & Remarks \\
\hline 1971 & 2.560 & 0.155 & 1.067 & 0.370 & 6.668 & \\
\hline 1972 & 2.728 & 0.195 & 1.167 & 0.609 & 7.783 & \\
\hline 1973 & 1.744 & 0.199 & 1.131 & 0.582 & 8.382 & \\
\hline 1974 & 2.667 & 0.325 & 1.566 & 0.931 & 9.040 & \\
\hline 1975 & 3.084 & 0.284 & 1.260 & 0.889 & 4.238 & \\
\hline 1976 & 3.119 & 0.282 & 1.449 & 0.888 & 5.247 & \\
\hline
\end{tabular}

Source: Olayide,S.O. (1980) Nigerian Small Farmers, Ibadan: University Press P.45

Table 2 - Yield of major food items 2000-2008 (In million tones) (Post-ADP period)

\begin{tabular}{|l|l|l|l|l|l|l|l|l|l|}
\hline Item & $\mathbf{2 0 0 0}$ & $\mathbf{2 0 0 1}$ & $\mathbf{2 0 0 2}$ & $\mathbf{2 0 0 3}$ & $\mathbf{2 0 0 4}$ & $\mathbf{2 0 0 5}$ & $\mathbf{2 0 0 6}$ & $\mathbf{2 0 0 7}$ & $\mathbf{2 0 0 8}$ \\
\hline Cassava & 11.86 & 8.92 & 8.01 & 12.55 & 13.49 & 12.50 & 10.64 & 9.81 & 7.50 \\
\hline Yam & 17.58 & 16.15 & 9.00 & 6.49 & 8.84 & 6.36 & 6.98 & 6.50 & 7.00 \\
\hline Maize & 2.19 & 2.91 & 1.51 & 2.07 & 2.09 & 1.60 & 1.71 & 1.00 & 1.80 \\
\hline Ground Nut & - & - & - & - & - & 1.64 & - & - & - \\
\hline Cowpea & - & - & - & - & - & - & 0.64 & 0.50 & - \\
\hline Rice & 1.33 & 3.5 & 3.00 & 3.37 & 2.90 & 3.42 & 2.27 & 2.35 & 3.50 \\
\hline Cocoyam & 14.07 & 11.73 & 10.41 & 5.34 & 7.05 & 7.63 & 9.17 & 9.20 & 9.40 \\
\hline Tomato & - & - & - & - & - & 1.19 & 0.94 & 1.00 & - \\
\hline
\end{tabular}

Source: ENADEP Implementation Completion Report, 2009) 
From the tables above, we could deduce that agricultural production in Nigeria did not improve with the advent of World Bank assisted ADP.

(2) Policy Design: The top-down approach that excludes beneficiaries from participating in the project design, planning, implementation, monitoring and evaluation as well as targeting the poor is not desirable (Okereke, 2009). Ugwu (2002) argues that the World Bank simply packaged a programme formulated for and tested in Asian countries to Nigeria without taking due consideration of the environmental, socio-political and economic factors of the people of Nigeria. According to him, the World Bank should have incorporated in the ADP policy, the right for the programme to have farms of its own for demonstration, hence knowledge is dynamic. Furthermore, the Bank ought to have phased the programme like phase 1 - Crop Phase 2 - Roads, Phase 3 - Building, water and irrigation, but all these were lumped together, thus making the programme very omnibus.

(3) Infrastructural Management: This has to do with the importation and installation of equipment of high technical nature without skilled manpower to run such equipment. The installation of obsolete equipment that their spare parts could not be easily sourced is yet another problem.

Ugwu (2002) argues that too much money was spent on infrastructures leaving very small sum for actual programme implementation. He further argues that some of the infrastructures were so sophisticated that the indigenous manpower could not access them, and therefore, they were either allowed to rot away or sold and the money shared among the ADP management and state governors. Olatunbosun (2000) also identified infrastructural problems and technical know how which results to poor equipment utilization as a hindrance to World Bank assisted agricultural development programme in Nigeria.

(4) Recruitment of Extension Agents: ADP Monitor (2006) reveals that some of the extension workers employed in ADPs in Nigeria are not experts in agriculture and therefore lack the skill to implement the programme. The reasons for this argue Nwabueze (2006) is high dependence on geographical spread and nepotism in recruitment process in ADP. This is a practice whereby consideration for employment or any other thing is carried out in such a manner as to recognize the diversity of the peoples within the state and the need to promote a sense of belonging among all the peoples in the federation. This is however against the merit system of recruitment. World Bank publication (1993) argues in strong terms on the need for effective manpower, especially the extension staff. Effective extension services smoothly transfer sustainable agricultural technologies to farmers. Equally essential is the need for extension services to transmit information to researchers regarding farmers' needs, problems and constraints. Lack of trained extension staff is a major constraint.

To corroborate the data from literature and interview, the researchers administered questionnaire to 30 ADP extension agents in Enugu State to elicit information on their educational background. The response as shown in table 3 indicates that most of the ADP extension agents have certificates that are of no relevance to agriculture. On further inquiry during face to face interview, the researchers gathered that some of the extension agents that have no certificate in agriculture - related areas were recruited based on political factors.

Table 3 - Data on educational qualification of respondents (extension agents)

\begin{tabular}{|l|c|c|}
\hline Educational qualification & Number & $\%$ \\
\hline Diploma in Agric related area & 5 & 16.66 \\
\hline Diploma in non-agric related area & 3 & 10.00 \\
\hline Degree in agric related area & 14 & 46.66 \\
\hline Degree in non-agric related area & 8 & 26.68 \\
\hline Total & 30 & 100 \\
\hline
\end{tabular}

Source: Field Survey (2009)

(5) Funding: The poor funding of ADPs is a problem of the three principal financiers (World Bamk, Federal and State governments) and it is not particularly in Enugu state, it cuts across other ADPs in the federation. The creation of nine new states in Nigeria including Enugu State in late August, 1991 has had lingering effects on administrative and operational efficiency of the ADPs especially in Enugu state and other new states, as managers, staff, facilities and equipment had to be relocated. The creation of ministries of agriculture, water resources and rural development from previously separated ministries of agricultural and rural development, of forestry and livestock, and of water resources added to the administrative difficulties that needed sorting out while programme implementation received less than adequate attention. 
In a number of states, the transfer of political authority to elected officials has been even more disruptive. Ugwu (2009) argues that Enugu State ADP under the regimes of Col. Mike Torey and Navy Captain Temi Ejoor as military governors experienced hard times as regards to state counterpart funding. It was during the periods under review that the Enugu State ADP staffers were owed several months of salary arrears.
Funding on the part of the World Bank seized to be effective starting from 1999. This is because the World Bank loan was fully drawn during the year in question. From 2000 the little sum the Bank disbursed to the ADPs in Nigeria was regarded as "on-going fund", essentially for the maintenance of existing structures in the programme. Tables 4 and 5 present the funding statement of ADP in Enugu State.

Table 4- ADP Enugu Funding Statement for period 1999-2007 N'000

\begin{tabular}{|c|c|c|c|}
\hline Year & Institution & Budgeted & Actual \\
\hline 1999 & $\begin{array}{l}\text { World Bank } \\
\text { Federal Govt. } \\
\text { State Govt. }\end{array}$ & $\begin{array}{l}70,274,000 \\
69,898,000 \\
11,450,000\end{array}$ & $\begin{array}{l}51,861,000 \\
15,816,000 \\
3,520,000\end{array}$ \\
\hline 2000 & $\begin{array}{l}\text { World Bank } \\
\text { Federal Govt. } \\
\text { State Govt. }\end{array}$ & $\begin{array}{l}55,833,000 \\
59,416,000 \\
15,833,000\end{array}$ & $\begin{array}{l}24230,000 \\
10,647,000 \\
2,431,000\end{array}$ \\
\hline 2001 & $\begin{array}{l}\text { World Bank } \\
\text { Federal Govt. } \\
\text { State Govt. }\end{array}$ & $\begin{array}{l}- \\
59818,000 \\
15,409,000\end{array}$ & $\begin{array}{l}9,250,000 \\
1,831,000\end{array}$ \\
\hline 2002 & $\begin{array}{l}\text { World Bank(MS ADP -1 on- } \\
\text { going) } \\
\text { Federal Govt. } \\
\text { State Govt. }\end{array}$ & $\begin{array}{l}8,500,000 \\
53,240,000 \\
10,600,000\end{array}$ & $\begin{array}{l}5,148,000 \\
9,600,000 \\
1,800,000\end{array}$ \\
\hline 2003 & $\begin{array}{l}\text { World Bank (MS ADP } 1 \text { on- } \\
\text { going) } \\
\text { Federal Govt. } \\
\text { State Govt. }\end{array}$ & $\begin{array}{l}7,110,000 \\
54,311,000 \\
12,141,000\end{array}$ & $\begin{array}{l}4,140,000 \\
10,170,000 \\
2,800,000\end{array}$ \\
\hline 2004 & $\begin{array}{l}\text { World Bank } \\
\text { Federal Govt. } \\
\text { State Govt. }\end{array}$ & $\begin{array}{l}6,450,000 \\
65,120,000 \\
12,450,000\end{array}$ & $\begin{array}{l}2,150,000 \\
12,115,000 \\
2,900,000\end{array}$ \\
\hline 2005 & $\begin{array}{l}\text { World Bank } \\
\text { Federal Govt. } \\
\text { State Govt. }\end{array}$ & $\begin{array}{l}- \\
60,315,000 \\
14,500,000\end{array}$ & $\begin{array}{l}- \\
10,300,000 \\
9,400,000\end{array}$ \\
\hline 2006 & $\begin{array}{l}\text { World Bank } \\
\text { Federal Go } \\
\text { vt. } \\
\text { State Govt. }\end{array}$ & $\begin{array}{l}- \\
30,300,000 \\
30,411,000\end{array}$ & $\begin{array}{l}- \\
8,150,000 \\
10,000,000\end{array}$ \\
\hline 2007 & $\begin{array}{l}\text { World Bank } \\
\text { Federal Govt. } \\
\text { State Govt. }\end{array}$ & $\begin{array}{l}10,130,000 \\
70,000,000 \\
33,000,000\end{array}$ & $\begin{array}{l}3,000,000 \\
10,150,000 \\
12,000,000\end{array}$ \\
\hline
\end{tabular}

Source: Enugu ADP Annual Report, 2009

Table 4 above reveals that World Bank funding was very effective between 1999 and 2000. In 2001 there was nothing under the World Bank column. When probed further Ugwu (2009), contends that the World Bank loan finished in 2001,. From 2002 the figures presented are what he described as "MS-ADP on-going" funding. The skeletal fund the Bank now provides is used to keep the ADP till a new credit line is opened.

The state fund which is strictly used to pay salary of workers increased between 2005-2007 in order to 
reflect the state government's upward review of workers wages. The state fund according to Nwabueze (2009), is a kind of standing order, which is in accordance with the counterpart agreement that the state would pay the workers salary. Thus the state government has never for once included ADP in the budget estimate, especially in the area of services the programme provides. To worsen the situation, the programme has no means of generating revenue internally.

Table 5- Selected States funding of ADPs, 2002-2004. Planned (P) and Actual (A) (Naira million)

\begin{tabular}{|l|l|l|l|l|l|l|}
\hline & 2002 & & 2003 & & 2004 & \\
\hline State & $\mathrm{P}$ & $\mathrm{A}$ & $\mathrm{P}$ & $\mathrm{A}$ & $\mathrm{P}$ & $\mathrm{A}$ \\
\hline Akwa Ibom & 14.2 & 2.5 & 18.1 & 5.9 & 15.4 & 9.3 \\
\hline Anambra & 15.5 & 33.6 & 12.5 & 11.4 & 8.4 & 6.2 \\
\hline Bauchi & 13.2 & 11.5 & 17.6 & 15.2 & 25.4 & 19.6 \\
\hline Benue & 24.5 & 6.4 & 23.0 & 6.4 & 19.4 & 0.4 \\
\hline Borno & 46.6 & 25.5 & 35.4 & 29.0 & 18.7 & 14.8 \\
\hline *Enugu & 13.5 & 7.5 & 11.45 & 3.5 & 15.83 & 2.4 \\
\hline Imo & 15.4 & 14.4 & 16.3 & 11.3 & 18.9 & 18.6 \\
\hline Kano & 35.0 & 23.5 & 36.9 & 33.2 & 35.2 & 21.1 \\
\hline Katsina & 22.3 & 11.3 & 25.0 & 18.2 & 23.4 & 30.5 \\
\hline Kwara & 7.4 & 7.2 & 14.2 & 7.6 & 17.9 & 8.4 \\
\hline Niger & 15.6 & 12.3 & 30.5 & 10.5 & 28.6 & 15.7 \\
\hline Ondo & 14.0 & 7.6 & 18.1 & 13.2 & 27.4 & 17.6 \\
\hline Oyo & 20.1 & 22.4 & 23.4 & 23.2 & 6.8 & 20.2 \\
\hline Plateau & 12.0 & 8.1 & 14.5 & 11.9 & 18.8 & 18.8 \\
\hline Rivers & 10.3 & 5.6 & 11.9 & 7.3 & 15.0 & 11.7 \\
\hline Sokoto & 18.2 & 19.8 & 33.4 & 29.2 & 28.2 & 20.4 \\
\hline
\end{tabular}

Source: World Bank Publication, Abuja: July, 2005

Table 5 above covered the period 2002 to 2004 because it was the period of effective funding from World Bank nationwide.

The study further reveals that the funding problem was made worse $b$ the undue delay in draw-down of fund from World Bank due to slow release of 'no objection letter' to state governments (ICR, 2009).

The foregoing indicates that poor funding has greatly affected the smooth execution of the World Bank assisted agricultural development programme in Nigeria.

(6) Leadership: Frequent changes in leadership also was discovered to impair the effective implementation of the ADP programme in Nigeria,

Nwabueze (2009) and Daily Star Newspaper July 14 (2008) reveal that between 2002 and 2007 Enugu State ADP had changed five programme managers. Different leaders with styles share a common interest of the people they purport to represent. Some of these programme managers were not appointed on professionalism /skill, and experience but based on the choice of the ruling class or military junta as the case may be. Since some of these managers were not professionals in agricultural sciences, their leadership could not make positive impact in agricultural development.

(7) World Bank performance: The World Bank has not also performed so well in the project preparation, appraisal and supervision. The problem is made worse by late delivery of aide memoirs. The World Bank aide-memoirs, which ought to help in programme implementation, were not delivered to the ADPs on good time. Furthermore, the frequency of supervision and intensity of supervision during the programme cycle was, however, not very satisfactory (ENADEP ICR, 2005). See table below. 
Table 6 - World Bank Performance

\begin{tabular}{|l|c|l|l|}
\hline & $\begin{array}{l}\text { Highly } \\
\text { satisfactory }\end{array}$ & Satisfactory & Deficit \\
\hline Identification & $*$ & & \\
Preparation & $*$ & & \\
Appraisal & & & $*$ \\
Supervision & & & $*$ \\
\hline
\end{tabular}

Source: ENADEP ICR, (2005)

(8) Extension Service: The ADP in Nigeria, operated a unified extension system as specified in the Staff Appraisal Report (SAR). The extension services had as its primary objective the establishment and organization of disciplined and well supported performance - oriented extension services. This is with the aim of motivating the small holder farmers to adopt relevant technologies in order to achieve significant increases in food production and income.

Extension activities however, progressed in 2003 with the introduction of radio and television programmes. $100 \%$ achievements were made in terms of number of radio and television programmes targeted (ICR, 2005). Supervisory visits to extension agents and contact farmers were however not reasonably done. Block meetings (85.0\%), fortnightly trainings (43.8\%) and monthly technology review meetings (MTRM) $(100 \%)$ were organized with fair percentage ratings against set targets. Fifteen thousand, eight hundred and forty $(25,840$ No.) contact farmers $(12.4 \%)$ were reached against 125.920 (No.) contact farmers target (ICR, 2005).

In $2003,36,840$ or $29.3 \%$ contact farmers were reached as against SAR estimate of $125,920$.

Table 7 - Key Implementation Indicators in SAR 2002-2000-2008
However, the situation improved in 2004. Staff strength improved by $84.8 \%$. About $47,850(38 \%)$ of contact farmers were reached out of targeted 125,920 as estimated in the SAR.

An extension agent ratio of 1:2884 was recorded in 2003 with a short fall of about $2 \%$ below that of the previous year (2002). This was due to staff resignations in search of better employments.

In summary, significant progress was not made in extension services during the project life (20002009). From the Implementation Completion Report (ICR, 2007), ADP has not made much impact in the area of agricultural extension and research. See table 7.

According to the field investigation, as presented in tables 8, 9, and 10, the responses elicited from farmers and extension agents indicates that the performance of ADP has not made serious impact on the lives of farmers. The data in table 8 revealed that the effort of ADP in the area of improved seedling is not significant. Out of the 30 respondents, 10 were of the opinion that ADP's provision of improved seedling is effective while 20 said that it is ineffective. Out of 30 respondents on fish pond management, 15 said that it is effective, while 15 said that it is ineffective. On seed multiplication, 9 respondents said that it is effective as against 21 respondents who said that it is ineffective. On erosion control, 5 respondents opined that it is effective while 25 said it is ineffective. On cassava multiplication, the responses were as follows: 10 people for effective and 20 people supported ineffective. However, the analysis revealed that ADP has performed well in upland rice technology. Out of 30 respondents, 20 people said it is effective while 10 said it is not effective.]

\begin{tabular}{|l|l|l|l|}
\hline SN & Crop & Target (\%) & Actual (\%) \\
\hline $\mathbf{1 .}$ & Yam/maize/cassava & 100 & 37.8 \\
\hline $\mathbf{2 .}$ & Upland rice & 100 & 50.27 \\
\hline $\mathbf{3 .}$ & Vegetable/kitchen gardening & 100 & 55.44 \\
\hline $\mathbf{4 .}$ & Rabitory & 100 & 18.84 \\
\hline $\mathbf{5 .}$ & Fisheries & 100 & 4.45 \\
\hline $\mathbf{6 .}$ & Yam miniset & 100 & 41.87 \\
\hline $\mathbf{7 .}$ & Cowpea & 100 & 35.8 \\
\hline
\end{tabular}

Source: ADP ICR, 2009 
Table 8 - Opinion of farmers and Extension agents on the administration of ADP in Nigeria (Farmers' view on the performance of ADP)

\begin{tabular}{|l|l|l|l|l|l|l|}
\hline & & $\begin{array}{l}\text { Frequency } \\
\text { For effective }\end{array}$ & $\%$ & $\begin{array}{l}\text { Frequency for } \\
\text { ineffective }\end{array}$ & \% & $\begin{array}{l}\text { Total } \\
\text { respondents }\end{array}$ \\
\hline (a) & Improved seedling & 10 & 33.33 & 20 & $\mathbf{6 6 . 6 7}$ & $\mathbf{3 0}$ \\
\hline (b) & Fish Pond mgt & 15 & 50.00 & 15 & $\mathbf{5 0 . 0 0}$ & $\mathbf{3 0}$ \\
\hline () & Seed multiplication & 9 & 30.00 & 21 & $\mathbf{7 0 . 0 0}$ & $\mathbf{3 0}$ \\
\hline (d) & Erosion Control & 5 & 16.66 & 25 & $\mathbf{8 3 . 3 4}$ & $\mathbf{3 0}$ \\
\hline (e) & Cassava multiplication & 10 & 33.33 & 20 & $\mathbf{6 6 . 6 7}$ & $\mathbf{3 0}$ \\
\hline (f) & Upland rice & 20 & 66.67 & 20 & $\mathbf{6 6 . 6 7}$ & $\mathbf{3 0}$ \\
\hline
\end{tabular}

Source: Field Survey,(2009)

Table 9 - Farmers' opinion about ADP impacting on their lives

\begin{tabular}{|l|l|l|l|l|l|l|}
\hline & Yes & $\%$ & No & $\%$ & & Total Respondents \\
\hline $\begin{array}{c}\text { (a) Has ADP contributed in } \\
\text { increasing your income } \\
\text { through agric dev.? }\end{array}$ & 10 & 33.33 & 20 & 66.67 & & \\
\hline $\begin{array}{c}\text { (b) Do you think tht the } \\
\text { ADP extension workers } \\
\text { have been able to e } \\
\text { educate the farmers } \\
\text { properly? }\end{array}$ & 12 & 40.0 & 18 & 60.00 & & 30 \\
\hline $\begin{array}{l}\text { (c) Has ADP built any } \\
\text { feeder road in your area? }\end{array}$ & 11 & 36.66 & 19 & 63.34 & & 30 \\
\hline $\begin{array}{c}\text { (d) Do extension agents } \\
\text { visit you often? }\end{array}$ & 14 & 46.66 & 16 & 53.34 & & 30 \\
\hline
\end{tabular}

Source: Field survey (2009)

Table 10 - Extension agents' view on the factors that impair the performance of ADP

\begin{tabular}{|l|l|l|l|l|l|l|}
\hline & Factors & Yes & $\%$ & No & $\%$ & Total Res. \\
\hline (a) & Poor equipment utilization & 14 & 46.66 & 16 & 53.34 & 30 \\
\hline (b) & Inadequate infrastructural provision & 17 & 56.66 & 14 & 43.34 & 30 \\
\hline (c) & $\begin{array}{l}\text { Non involvement of programme } \\
\text { Beneficiaries in policy planning }\end{array}$ & 17 & 56.66 & 14 & 43.34 & 30 \\
\hline (d) & Poor funding/fund utilization & 16 & 53.33 & 14 & 46.67 & 30 \\
\hline (e) & Government undue interference & 16 & 53.33 & 14 & 46.67 & 30 \\
\hline
\end{tabular}

Source: Field survey (2009) 
A survey was also carried out to investigate how ADP has contributed in the income of farmers. Out of 30 respondents, 10 said that $A D P$ has contributed to their income, while 20 said that ADP has not. A survey was also carried out to determine the role of the extension agents to educate the farmers. Out of 30 respondents, 12 people were positive while 18 were not. Out of the 30 respondents, only 11 agreed that ADP has constructed feeder roads in their area. The investigation further revealed that extension agents do not visit the farmers regularly.

Table 10 reveals that a number of factors in the opinion of the farmers constituted problem to ADP. These factors include inadequate infrastructural provision, non-involvement of the farmers in policy planning, poor funding/fund utilization and government undue interference in the running of the ADP.

Table 11 - Relative Ranking of the performance of ADP in Nigeria

\begin{tabular}{|l|l|l|}
\hline & Factor & \% of respondent \\
\hline 1 & Improved seedling & $\begin{array}{l}33 \text { (of those } \\
\text { administered } \\
\text { questionnaire }\end{array}$ \\
\hline 2 & Fish pond management & 50 (" ) \\
\hline 3 & Seed multiplication & 30 (") \\
\hline 4 & Erosion control & 16.66 (") \\
\hline 5 & Cassava multiplication & 33.33 (") \\
\hline 6 & Upland rice & 66.67 (") \\
\hline 7 & Income through agriculture & 33.33 (") \\
\hline 8 & $\begin{array}{l}\text { Education of the farmers } \\
\text { on agricultural technology }\end{array}$ & 40.00 (" _) \\
\hline 9 & $\begin{array}{l}\text { Construction of feeder } \\
\text { roads }\end{array}$ & 36.66 (") $)$ \\
\hline 10 & Visit by extension agents & 46.66 (") \\
\hline
\end{tabular}

Source: Compiled from tables 8 and 9.

The table above revealed that amongst the factors assessed, upland rice technology ranked highest according to the recipients of the technology (i.e. the farmers who responded to the questionnaire), followed by fish pond management, while visit by extension agents took the rear. This however suggests that the operators of the ADP should spend more time in the areas like improved seedling, seed multiplication, erosion control, cassava multiplication, construction of feeder roads. The implication of the information in this table therefore is that the policy planers and the operators of ADP in Nigeria should take cognizance of this relative ranking and note the forces that impair ADP performance.

\section{RECOMMENDATIONS}

The following recommendations are proffered to help tackle the problems and challenges that were captured in this paper, which militate against good management of foreign grants/loans and sustainable agricultural development in Nigeria. Only a few laudable achievements have been recorded for World Bank agricultural programmes, therefore, many areas need to be fine-tuned in order to make the policies and programmes more meaningful to the needs of the benefiting communities:

(1) Skilled manpower (especially extension staff) should be employed and would be encouraged to visit farmers on regular basis to teach them modern agricultural technology. If the farmers across the federation of Nigeria begin to put into use the new agricultural technology, there is likely to be an improvement in the growth of crop production.

(2) It is the position of this paper that the management of ADP should explain properly to the government the need to maintain a recruitment policy based on merit as well as less government intervention in the recruitment matters.

(3) The Federal Government of Nigeria should as a matter of necessity, redesign the Agricultural Development Programme to give each state ADP a corporate status to procure development loans on its own capacity.

(4) State governments should take more responsibility by making yearly budgetary allocation to the programme instead of the usual counterpart funding.

(5) As the ADP does not generate money internally, some of its professional services should be commercialized to be in line with the Federal Ministry of Agriculture's proposal. However such services should be subsidized. Those to be included are seed multiplication, livestock and feed production.

(6) There is need to involve the programme beneficiaries in the design, planning and execution of projects. This will equally avoid top-down approach in policy co-ordination. It will also stimulate the interest of the beneficiaries or host communities. 
(7) There is need for Nigeria to ensure a peaceful political atmosphere, as no meaningful development will take place in a country bedeviled by internal or external political and social strife. With peaceful political atmosphere and stability in leadership of the ADPs, the issue of poor policy performance which has been the bane of the development efforts of Nigeria will now be a thing of the past.

(8) There is need to identify and target the poor in project implementation. It is on record that most often, project designed to benefit the poor, more often than not end up benefiting the rich in the society especially the case of the World Bank Agricultural Development Programme. Therefore it is the candid opinion of this paper that the poor should be identified and conscious effort made to ensure that projects designed for them really get to them.

(9) The policy planners and operators of ADP should take cognizance of the relative ranking of ADP's performance in table 11 above to guide them to perform better.

\section{REFERENCES}

Abah, N.C. (2001) Development Administration: A Multidisciplinary Approach, Enugu:John Jacobs Classic Publishers.

Afigbo, A.E. (2000) "Towards Understanding Community Development through self -Help: The Nigerian Experience" in Aja A. Aja and Emeribe A (eds.), PolicyAnd Contending Issues in Nigerian National Development, Enugu: John Jacobs Classic Publishers. ADP Monitor (1997)p. 6

ADP Monitor (2006) p.4

ADP Implementation and Completion Report (2009) pp. 4-5

Chukwuemeka, E (2004) "World Bank and Agricultural Development In Enugu State" ESUI Journal of Administration, 1(2) 56-70

Central Bank of Nigeria Annual Abstract (2007) p.45

Daily Star Newspaper, (July 14, 2006) p. 13

Eze, F, Chukwuemeka, E and Abah N (1998) Public Administration and Development The Nigerian Experience, Enugu: Marydan Publishers.

ENADEP Implementation Completion Report (2005) p. 23

ENADEP Annual Report (1996) p.15

Eteng, B. (1976) "Managing Agricultural Development in Nigeria: The basic facts" Journal of Tropical Agriculture, 5(4) 17-23
Famoriye, S (1998) "Food Production Policies in Nigeria" Pan African Journal Of Social Research 1(1) 20-25

Iheagu, O (2002) Food Crisis in Africa, Lagos: Turning Point Publishers

Nwabueze M (2009) Interview conducted onss him on $12^{\text {th }}$ March,.

Nigerian Bureau of Statistics (2007) Statistical Abstract p.19

Onyeahialam, V. (2002) "Administration of Agricultural Development Programme Towards SocioEconomic Development of Nigeria" Journal of Policy and IDevelopment Studies, 1(2) 15-23

Obasanjo O (2002) Why We should not neglect agriculture, Newswatch Magazine, June, pp. 4-6

Obniajulu A (1997) "Nigerian Economic Recovery Strategies: An Appraisal" in Orjiako N, and Unachukwu, G (eds), Socio-Political Development: Issues and Prospects Enugu: John Jacob Classic Publisers.

Olatunbosun, D (2005) Nigeria's Neglected Rural Majority, Ibadan: Oxford University Press.

Onimode, B (2008), A Political Economy of African Crisis, London: ZED Books.

Orjiani, K. (1987) "The Politics of World Bank Agricultural Development Programme" African Development Review, 4(4) 4-10

Ojowu, O (1987) "Nigeria's Structural Adjustment Budget" Nigerian Journal of Contemporary Public Issues, 2(2) 14-20ssss

Olayide, F (1980) "The Problems and Prospects of Agricultural Produce Exportation In Nigeria" Journal of Africa in a New World Order, 1(1) 45-51

Okereke, O (2000) "Colonial and Post Colonial Agrarian Policies in Nigeria: Lessons and Polity Option" in Aja A. Aja and Emeribe A (eds) Policy and Contending Issues in Nigerian National Development Strategy, Enugu: John Jacobs Classic Publishers.

Tamuno, G (2006) "How to curb Food Crisis in Nigeria" Journal of Sustainable Development, 3(2) 20-25

Umebali, E (1999) "The Role of ADP in Agricultural Development" ESUT Journal Of Development, 1(2) 1522

Uzoigwe, D (2007) Principles of Crop Management, Lagos: Vinez Publishers.

Ugwu, D (2009) Interview conducted on him in ADP, $10^{\text {th }}$ March World Bank Publications (1995) pp. 12-13 